\title{
Performance Analysis of China's Fast Fashion Clothing Market Based on SCP Model
}

\author{
Lu Ge1, Xuran Sun ${ }^{1}$, Chenggang $\mathbf{L i}^{2 *}$ \\ ${ }^{1}$ Department of Business Administration, Fashion Brand Management, Business School of BIFT, Beijing, China \\ ${ }^{2}$ Department of Network Economy, Electronic Business, Network Marketing, Management Innovation, Business School of BIFT, \\ Beijing, China \\ Email: *ccid205@126.com
}

How to cite this paper: Ge, L., Sun, X.R. and Li, C.G. (2019) Performance Analysis of China's Fast Fashion Clothing Market Based on SCP Model. Open Journal of Business and Management, 7, 106-115. https://doi.org/10.4236/ojbm.2019.71007

Received: November 15, 2018 Accepted: December 16, 2018 Published: December 19, 2018

Copyright (๑) 2019 by authors and Scientific Research Publishing Inc. This work is licensed under the Creative Commons Attribution International License (CC BY 4.0).

http://creativecommons.org/licenses/by/4.0/

\begin{abstract}
China's fast fashion clothing market is dominated by Uniqlo, ZARA and $\mathrm{H}$ \& $\mathrm{M}$, supplemented by other fast fashion clothing brands. This paper uses SCP paradigm to analyze the fast fashion brands in China's clothing market. By dividing the market structure of China's fast fashion clothing, it is concluded that the market structure of China's fast fashion clothing is oligopoly III, and the cost oriented price behavior of enterprises in the oligopoly market structure is analyzed. In order to analyze the market performance of China's fast fashion clothing market, digital non-price behavior and organizational adjustment behavior of increasing the number of stores are used to analyze the market performance of China's fast fashion clothing market.
\end{abstract}

\section{Keywords}

Fast Fashion Clothing, SCP Paradigm, Structure, Conduct, Performance

\section{Introduction}

The theoretical framework of SCP refers to the market structure in industry (structure), market behavior (Conduct) and market performance (Performance). Market structure refers to the form and characteristics of market relationship between enterprises, and it is the environment of economic operation. Enterprise conduct is an action taken by an enterprise in the market to achieve its goal, and these actions are often in order to adapt to the market structure. Market performance refers to the state and effect of a certain industry in all aspects under a certain market structure and operating environment [1]. With the globalization of the global economy, the fast fashion clothing consumption initiated by foreign countries also landed on the Chinese clothing market at the beginning 
of the 20th century. Based on the SCP theory, this paper studies the market of China's fast fashion clothing industry by selecting the enterprises that rank first in the sales volume in China's fast fashion clothing market. Field structure, market behavior and market performance are considered as a complete framework system to analyze the interaction between them.

As a huge clothing consumption market in China, fast fashion clothing market occupies an important share in the whole domestic clothing market. From 2006, ZARA entered the Chinese clothing market for the first time, with a brand new fashion sales model [2]. Since then, domestic and foreign fast fashion brands have poured into the Chinese market, and fast fashion has swept the Chinese clothing market with a rapid trend.

\section{The Structure of China's Fast Fashion Clothing Market}

As an important research method in the theory of industrial organization, SCP paradigm firstly analyzes the market structure, which reflects the relationship between competition and monopoly among industries. The market structure of China's fast fashion garment industry can be analyzed from three aspects: market concentration degree, product differentiation degree and barriers to fast fashion clothing industry in and out of China.

\subsection{Market Concentration}

The concentration of fast fashion clothing market refers to the market share occupied by a few largest enterprises in the fast fashion clothing market. The higher the market concentration, the greater the value. There are two ways to measure market concentration: one is absolute method and the other is relative method. The absolute method is to calculate the market share of the first few enterprises directly, and the absolute method to calculate the index is the concentration coefficient. Calculation

$$
C R_{n}=\sum_{i=1}^{n} X_{i} / \sum_{i=1}^{N} X_{i}
$$

formula: $C R_{n}$ - The largest in the industry The degree of industry concentration; $X_{i}$-Industry in the first place Value of output, sales, etc.; $n-$ Number of enterprises in the industry; $N$-Total number of enterprises in the industry [3].

The market share of the top three fast fashion brands in China's fast fashion clothing market is obtained by investigating the market sales of fast fashion clothing brands. Among them, $\mathrm{H} \& \mathrm{M}$ is the only one that has reported its annual sales in China at 8.85 billion yuan [4]. ZARA (including Pull\&bear, Bershka and other sub-brands) reported global sales of $€ 16.62$ billion, Asian market share $23.2 \%$ and $17.8 \%$ of the Asian market in China on the 2017 annual report [5]. Uniqlo reported sales of 2.81 trillion yen in 2017 and 70\% of overseas markets in China [6]. We calculated the sales of 11.81 billion yuan. According to the data center of win Business Network, China's fast fashion clothing sales in 2017 accounted for $32 \%$ of the total brand clothing sales, 2017 brand clothing sales 
total 123.8 billion yuan, can be calculated 2017 China fast fashion clothing sales of 39.616 billion yuan (Table 1 ).

China's fast fashion apparel industry market is dominated by Uniqlo, ZARA and $\mathrm{H} \& \mathrm{M}$, which account for most of the market share. From the perspective of market concentration, the sales of Uniqlo, H \& M and ZARA in China in 2017 are added together:

$$
\sum_{i=1}^{3} X_{n}=26.104 \text { billion yuan, } \sum_{i=1}^{N} X_{n}=39.616 \text { billion yuan }
$$

According to formula (1) the Bain Market structure Classification (Table 2) $65.8<C R_{4}<79.5$ and $50 \leq C R_{4}<85$, it is concluded that the fast fashion clothing market in China is oligopolistic type III.

\subsection{Great Degree of Product Differentiation}

Product differentiation means that enterprises influence consumers' purchase by triggering the particularity of products in consumers' minds [7]. Product differentiation is another important factor that affects the market structure. The so-called product differentiation refers to the product that the enterprise provides to customers in front of it, which is sufficient to cause consumer preference through various marketing methods. Enable customers to separate their competing products, thus creating a competitive advantage in the market.

Fast fashion clothing brand product differentiation, the greater the degree of product differentiation clothing brand companies, the more successful will be able to distinguish their own brands and similar clothing brands, so that they

Table 1. Market sales of China’s Fast Fashion Clothing Brand in 2017 [4] [5] [6].

\begin{tabular}{ccc}
\hline Brand & Sales (billion yuan) & Proportion (\%) \\
\hline Uniqlo & 11.81 & 29.8 \\
H \& M & 8.85 & 22.3 \\
ZARA & 54.44 & 13.7 \\
Other & 13.512 & 34.1 \\
All & 39.616 & 100 \\
\hline
\end{tabular}

Table 2. Bain market structure classification [3].

\begin{tabular}{lcc}
\hline & \multicolumn{2}{c}{ Market structure } \\
Concentration ratio & $1 . C R_{4}$ & $2 . C R_{8}$ \\
\hline Oligopoly type I & $75 \leq C R_{4}$ & - \\
Oligopoly type II & $75<C R_{4} \leq 85$ & or $85 \leq C R_{8}$ \\
Oligopoly type III & $50<C R_{4}<85$ & $75 \leq C R_{8}<85$ \\
Oligopoly type IV & $35 \leq C R_{4}<50$ & $45 \leq C R_{8}<75$ \\
Oligopoly type V & $30 \leq C R_{4}<35$ & or $40 \leq C R_{8}<45$ \\
Competitive type & $C R_{4}<30$ & or $C R_{8}<40$ \\
\hline
\end{tabular}


form a unique competitive advantage in the market, And more monopoly nature. So each brand shows different characteristics: ZARA strong supply chain, vertical shipping, greatly shorten the shipping time: an average of 2 weeks, $\mathrm{H} \&$ $\mathrm{M}$ has been cross-border cooperation to attract attention, improve the commodity price ratio; Uniqlo is a new way, from the fabric of clothing, through the study of the performance of clothing fabrics, but the style is simple and comfortable, The crowd is wider and so on.

\subsection{Higher Barriers to Advance and Retreat}

Barriers to entry and exit are barriers to changes in market competition caused by entry or exit from specific industries [8]. As far as the whole clothing market is concerned, the scale economy of garment industry is not obvious, and the barrier to entry is weak. Garment industry assets are professional, exit barriers strong, stock adjustment difficult.

However, for China's fast fashion clothing industry market, entry and exit barriers are high.

- Barriers to entry caused by economies of scale.

At present, foreign famous brands have occupied the main market in the fast fashion clothing market of our country, both in the perfect supply chain and in the intensive degree of the market stores, all of them have reached certain economies of scale.

- A barrier to entry formed by product differentiation.

The domestic fast fashion clothing brand has developed and matured, the consumer's preference for the brand has already formed, the preference for the original fast fashion clothing enterprise product is also higher than the new enterprise product, and even it is difficult to introduce the new enterprise product.

- A barrier to entry caused by costs.

When new enterprises enter the market, they spend more on marketing, besides the cost of building factories, and the cost of obtaining resources is much higher than that of old ones, so the barriers to entry are stronger.

- Expense barriers to exit

For the existing scale of fast fashion apparel enterprises in China, fast fashion clothing exit obstacles. Fast fashion companies, such as ZARA, H \& M and Uniqlo, have opened many stores in China, and when they exit the market, they have to close their stores, spend rents on the early days of the stores, decorate the costs and pay back the money they have to pay to lay off workers.

\subsection{Market Structure Decision Result}

From the angle of market concentration, the fast fashion clothing market of our country is oligopoly III. From the perspective of the interval $65.5<C R_{4}<79.5$, the fast fashion clothing market in China has a strong monopoly; Judging from the degree of product differentiation, the fast fashion brands represented by Uniqlo, ZARA and $\mathrm{H} \& \mathrm{M}$ have formed their unique core competitiveness through product differentiation, which other fast fashion clothing brands cannot 
imitate. Thus forming oligopoly market; from the perspective of industry entry and exit barriers, because the operation of fast fashion brand clothing not only needs to achieve a certain scale economy, but also needs strong funds to support, so the entry and exit barriers of the industry are the higher, once again confirms the fast fashion clothing market is the oligopoly market type.

\section{Fast Fashion Market Conduct in China}

According to the classification of Bain market structure, the market structure of fast fashion apparel industry in China is oligopolistic type III. Based on the theory of SCP paradigm, enterprise behavior is an action taken by an enterprise in the market in order to achieve the goal of the enterprise, and these actions are often to adapt to the market structure. Its market behavior is usually restricted by the industrial market structure and counteracts to the market structure. The market behavior of fast fashion clothing in China is mainly characterized by the price behavior based on cost, the non-price behavior of digitization and the optimization of sales channels, and the organization behavior of rapidly expanding the number of stores [9].

\subsection{Cost-Oriented Pricing Behavior}

Fast fashion clothing industry is mostly cost-oriented pricing, accompanied by regular price discounts and promotion pricing. Cost-oriented price behavior leads to the low price of clothing, which greatly reduces the traditional fashion price, makes consumers scramble for it, and makes enterprises occupy market share quickly. Price behavior is the main competitive means of fast fashion clothing industry in the market.

Table 3: On the one hand, the three fast fashion brands have low starting point of clothing pricing, adopt competitive pricing strategy to attract consumers, so as to achieve the effect of quickly occupying market share; On the other hand, from the relatively high price number, fast fashion clothing enterprises not only grasp the low end consumer group, but also focus on the middle end customers, the price of each category can be reflected. In summary, the cost oriented price behavior of fast fashion clothing forms a price advantage in the clothing sales competition, which is aimed at the middle and low end consumer groups and is the mainstream of the clothing consumption market in our country. This will bring good market performance feedback.

\subsection{Non-Price Behavior Based on Digitization, Science and Technology and Optimization of Sales Channels}

\section{- Digitization}

With the rapid growth of our country's economic level, the structure of garment industry is changing, from simple price competition to comprehensive strength competition of brand and science and technology. As a leading fashion consumption industry, fast fashion enterprises should be aware of this to deal 
Table 3. China fast fashion brand adult clothing category price belt [10].

\begin{tabular}{ccccc}
\hline Brand & T-shirt (yuan) & Casual pants (yuan) & Skirt (yuan) & Cotton-padded clothes (yuan) \\
\hline Uniqlo & $39-148$ & $99-299$ & $9-299$ & $199-1099$ \\
ZARA & $39-299$ & $89-599$ & $99-1299$ & $199-1699$ \\
H \& M & $39-499$ & $79-449$ & $70-1790$ & $149-1990$ \\
\hline
\end{tabular}

with current consumption. The consumers of fast fashion clothing pursue fashion sense, pursue new things, and pay more attention to the experience of buying. Therefore, fast fashion clothing enterprises should keep pace with the times, rely on new technology, digitize, and rely on science and technology to enable the brand, as Table 4 "fast fashion brand digitization, science and technology specific practice" shows.

- Sales channel optimization

With the rapid development of information technology, online clothing consumption has become one of the most important consumption channels for consumers. Fast fashion clothing brands also break through online and offline barriers to achieve full-channel retail, and multi-channel network sales, competition is no less intense than offline. Each big fast fashion brand in the original already has the own net shop foundation, one after another has entered Tmall's flagship store, JingDong self-service store, WeChat Mini Program is also one of the sales methods. Four fast fashion brands in china e-commerce sales channels are shown in Table 5 .

\subsection{A Sharp Increase in the Number of Stores, Organizational Adjustment Behavior}

As a result of the foreign fast fashion brand joining unceasingly and the domestic emerging fast fashion brand rising, the organization adjustment behavior that the storefront quantity increases sharply becomes the fast fashion clothing enterprise in the existing market of our country to speed up the development. Maintain or expand the market share, thereby maintaining competitive advantage of an effective way. In order to maintain the original oligopoly market structure, the fast fashion clothing enterprises in the domestic market rapidly attack the land and rapidly increase the number of stores in China, in order to maintain or expand the original market share. Major fast fashion clothing brand stores have also spread across the country's major shopping malls. According to incomplete statistics, including $\mathrm{H} \& \mathrm{M}$ Zara, Uniqlo, MJ Ten fast fashion brands, including style, MUJI, NEW LOOK, UR, C \& A, Forever 21 gap, opened 88 stores in the mainland in the third quarter of 2017.

At the same time, according to the 2018 China Fast Fashion clothing Industry Analysis report-the market operation situation and investment prospects study, the number of fast fashion brands in China is still growing, Uniqlo has the highest increase, reaching $19.52 \%$. China's fast fashion apparel market has been presented by Uniqlo and H \& M \& M Inditex Group “three feet” (Table 6). 
Table 4. The concrete practice of digitization and Science and Technology of Fast Fashion Brand.

\begin{tabular}{cl}
\hline Brand & \multicolumn{1}{c}{ Activity } \\
\hline Uniqlo & $\begin{array}{l}\text { Uniqlo opened the world's newest concept store in Shenzhen. For the first time, } \\
\text { Uniqlo has launched a "digital experience museum" that integrates online and } \\
\text { offline, connecting entities with virtual experience. } \\
\text { To remedy the slowdown, ZARA has also incorporated new technology into its stores } \\
\text { to add a sense of experience. In April, Zara launched a two-week AR experience at } \\
\text { ZARA stores around the world. }\end{array}$ \\
H\&M $\begin{array}{l}\text { In order to reduce inventory pressure and promote the growth of single store } \\
\text { turnover, consider using big data analysis, according to different regions of consumer } \\
\text { preferences, different categories of shares to change the global unified distribution, } \\
\text { while creating more characteristic stores. }\end{array}$
\end{tabular}

Source: open data collation.

Table 5. Four fast fashion brands, Chinese e-commerce sales channels.

\begin{tabular}{|c|c|c|c|c|c|}
\hline Brand & $\begin{array}{c}\text { Own-account } \\
\text { shop }\end{array}$ & Tmall & JingDong & Small routine & $\begin{array}{c}\text { Mini Programs } \\
\text { sales }\end{array}$ \\
\hline Uniqlo & & & Closed & 1 & None \\
\hline ZARA & & & None & 1 & \\
\hline$H \& M$ & & & None & 2 & None \\
\hline Gap & & & Closed & 2 & \\
\hline
\end{tabular}

Source: open data collation.

Table 6. Number of new stores for fast fashion brands in the first and third quarters of 2017 [4] [5] [6].

\begin{tabular}{cccc}
\hline Brand & $\begin{array}{c}\text { Number of new stores in } \\
\text { the first half of } 2017\end{array}$ & $\begin{array}{c}\text { Number of new stores in the } \\
\text { third quarter of 2017 }\end{array}$ & $\begin{array}{r}\text { Total number of } \\
\text { stores as of } 2017\end{array}$ \\
\hline Uniqlo & 34 & 20 & 900 \\
ZARA & 7 & 2 & 260 \\
H \& M & 21 & 14 & 506 \\
Gap & 1 & 1 & 170 \\
\hline
\end{tabular}

\section{Performance of Fast Fashion Garment Market with Oligopoly Type III}

Fast fashion clothing market performance is based on a certain oligopoly type III market structure, through the clothing enterprises market behavior resulting in its industry formation of resource allocation and benefit distribution state. China's fast fashion clothing industry has been developing rapidly since 2006, and its market performance is mainly characterized by rapid growth. The market performance is measured by the efficiency of resource allocation and the level of scale economy of enterprises.

\subsection{Resource Allocation Efficiency}

Resource allocation efficiency is one of the important indicators to measure 
market performance, while profit rate is the main index to measure resource allocation efficiency. The higher the profit margin and the more operational cost, the higher the resource allocation efficiency. The profit of China's fast fashion industry is higher than that of the whole garment industry, and the gross profit rate is above $45 \%$. The higher the gross profit rate and the higher the profit margin of the fast fashion garment industry, the higher the resource allocation efficiency is, and the higher the market concentration and monopoly is, the more oligopolistic the market is (Table 7).

The main reason for the high efficiency of resource allocation in the fast fashion clothing industry is the high efficiency of the supply chain. The production and operation cycle of the fast fashion clothing industry is from two weeks to one month, while the production cycle of the general clothing industry is divorced from the fashion industry. The period is 3 months, compared with the fast fashion industry, the production and operation cycle is much faster than the general industry, and on this basis, the fast fashion clothing industry can make a profit first. The second is the production of fast fashion clothing in heavy type, light quantity, and different from the general clothing industry in batch production of the same clothing, therefore, fast fashion clothing industry in the stock backlog pressure is also smaller than the overall clothing industry.

\subsection{Enterprise Scale Economy Level}

The level of scale economy is an important index to measure the market performance of enterprises, among which the mode of enterprise management is the important reason for the formation of scale economy of enterprises. The enterprises above the scale in the fast fashion clothing market in our country are all SPA business model, that is, the independent brand professional retailer management mode, from commodity planning, manufacturing to retail integration of vertical sales model. In this mode, the production is directly connected to the retail, the product is directly faced with the customer, and the customer and the supplier are effectively connected at the same time, so that the rapid response to the market is realized, which not only increases the speed of flow, but also compresses the operating cost. Such a business model has effectively increased the size of the enterprise Economic level [11].

Take ZARA's business model as an example, from design products to ready-to-wear shelves, fabric procurement to clothing production, store sales display, commodity distribution to customer feedback, each link with the extreme,

Table 7. 2016 Uniqlo, H \& M Zara Global main Business revenues, profits [4] [5] [6].

\begin{tabular}{cccc}
\hline Brand & $\begin{array}{c}\text { Main operating income } \\
\text { (billion yuan) }\end{array}$ & Net margin (billion yuan) & Gross profit rate (\%) \\
\hline Uniqlo & 170.505 & 23.417 & 57 \\
H \& M & 112.571 & 3.025 & 48.2 \\
ZARA & 146.46 & 14.171 & 55.2 \\
\hline
\end{tabular}


sensitive supply chain is the key factor to win of ZARA [12]. Fast fashion clothing enterprises in the relatively complete business model framework, can faster meet the existing needs of consumers. It is this kind of efficient management mode that makes the market performance of our country's fast fashion clothing industry grow rapidly.

\section{Concluding Remarks}

Based on the analysis of the concentration degree of market structure, the degree of product difference and the barriers of entering and leaving the domestic fast fashion garment industry, this paper concludes that the type of fast fashion clothing industry in China is oligopoly type III. Each fast fashion clothing brand enterprise has adopted the cost-oriented price behavior, the digitization, the science and technology as well as the sale channel optimization primarily non-price behavior and the organization adjustment behavior which increases the store quantity rapidly. From the point of view of market performance, the efficient management mode of fast fashion garment enterprises makes their turnover ahead of other clothing industries, and the business scale of enterprises is also expanding.

From the market structure, market behavior and market performance of fast fashion industry, fast fashion model has many advantages. The first is accurate positioning, whether in the product design, or in the customer positioning selection, are clear direction; the second is the production and sales, because of the complete production and management mode of fast fashion clothing enterprises, forming its unique competitive advantage in the industry; finally, the price advantage to provide consumers with design sense of fashion clothing at low prices.

To sum up, fast fashion clothing in the Chinese clothing market has a great potential for development. Domestic fast fashion clothing brands should also keep pace with the times, rapidly develop their own brands, improve their popularity, and change the situation of foreign fast fashion clothing brands' oligopoly in China's fast fashion clothing market. At the same time, it is also to realize the industry upgrade from garment production to clothing creation as soon as possible.

\section{Acknowledgements}

Fund Project: Beijing Municipal Education Commission's Social Science Program General Project-Research on the Dynamic Mechanism of Fashion Enterprise Innovation (AL2017-13); "Special fund for the construction of high-level teachers in Beijing Institute of Fashion Technology"-Beifu Scholars Program, project number: BIFTXZ201803; The "2017 Light of Textiles" China Textile Industry Federation Higher Education Teaching Reform-innovation and entrepreneurship education into professional personnel training reform and practice of one of the results. 


\section{Conflicts of Interest}

The authors declare no conflicts of interest regarding the publication of this paper.

\section{References}

[1] Lu, A. and Shu, S.L. (2013) Organization of Garment Industry. Personal Name Publishing House, 77.

[2] Wei, B.B. (2017) A Study on the Influence of Garment Matching Design of Fast Fashion Brand Clothing Store on Consumption Behavior-Market Research Report Based on ZARA, H \& M, ME \& CITY. Beauty and Times (I), No. 7, 98-101.

[3] Bain, J.S. (1981) Industrial Organization. Maruzen, 141-148.

[4] H\&M, GROUP. 2017 Annual Report. http://about.hm.com/content/dam/hmgroup/groupsite/documents/masterlanguage/ Annual\%20Report/Annual\%20Report\%202017.pdf

[5] INDITEX, GROUP. 2017 Annual Report. http://www.inditex.cn/documents/10279/563475/2017+Inditex+Annual+Report.pdf /f5bebfa4-edd2-ed6d-248a-8afb85c731d0

[6] FASTRETAILING, GROUP. 2017 Annual Report. https://www.fastretailing.com/eng/ir/library/pdf/ar2017_en.pdf

[7] Li, M.J., Li, S.N. and Lu, A. (2018) Market Analysis of China's Sportswear Industry based on "Structure-Behavioral-Performance" Paradigm. Wool Spinning Technology, No. 2, 81-86.

[8] Xia, L. and Zhao, L. (2018) On the Development of Rural Credit Cooperatives Based on SCP Paradigm. Journal of Beijing University of Agriculture, 2, 2.

[9] Panagiotou, G. (2006) The Impact of Managerial Cognitions on the StructureConduct-Performance (SCP) Paradigm: A Strategic Group Perspective. Management Decision, 44, 423-441. https://doi.org/10.1108/00251740610656296

[10] Tmall. http://www.tmall.com/

[11] Zhang, F. (2014) Research on Marketing Strategy of Fast Fashion Garment BrandTake ZARA as an Example. Guangdong Foreign Language University of Foreign Trade, Guangzhou.

[12] Tao, S. (2010) Marketing Characteristics of "Fast Fashion" Clothing Brand and Its Enlightenment to the Upgrading of China's Garment Industry. Economic Research Guide Journal, No. 24, 166-167. 